\title{
A new species of damselfish (Pomacentrus: Pomacentridae) from western New Guinea
}

\author{
Gerald R. Allen ${ }^{1}$ and Mark V. Erdmann ${ }^{2}$ \\ ${ }^{1}$ Department of Aquatic Zoology, Western Australian Museum, Locked Bag 49, Welshpool DC, \\ Perth, Western Australia 6986, Australia. \\ ${ }^{2}$ Conservation International, Jl. Dr. Muwardi No. 17, Renon, Denpasar 80235, Indonesia.
}

\begin{abstract}
Pomacentrus fakfakensis is described from 13 specimens, 17.7-57.0 $\mathrm{mm}$ SL, collected at the southern Bird's Head Peninsula of western New Guinea (Irian Jaya Barat Province, Indonesia). It is distinguished from most similar species in the western Pacific by possessing 14 instead of 13 dorsal-fin spines. The only other drab-brown (when alive) Pomacentrus from the region with 14 dorsal spines, $P$. opisthostigma and P. armillatus, are distinguished by dark markings (thin bar or wedge-shaped mark) on the pectoral-fin base as well as having fewer lateral-line scales (usually 15-17 versus 18-19), fewer pectoral rays (17 versus 18, occasionally 17$)$ and more gill rakers on the first arch (26-29 versus 19-21). The new species inhabits shallow reef flats around rock and coral outcrops, generally at depths less than about $8 \mathrm{~m}$.
\end{abstract}

\section{INTRODUCTION}

Damselfishes of the genus Pomacentrus Lacepède, 1802 are common inhabitants of coral reefs throughout the Indo-west and central Pacific Ocean. Allen (1991) recognized 54 species, but since then an additional 15 species have been described (Allen 1992, 1993, 1995, 1999, 2002, 2004; Randall 2002; Allen and Wright 2003; Allen and Randall 2004, 2005). It is the second largest genus in this major reef-fish family that contains approximately 360 species globally, being surpassed only by Chromis Cuvier, 1814 with 86 species (Allen and Erdmann 2005). The majority (about 68\%) of Pomacentrus are primarily distributed in the western and central Pacific region, with lesser representation in the Indian Ocean. The genus is particularly well represented in the diverse Indo-Australian Archipelago where approximately 50 species are known to occur.

The present paper describes a new species of Pomacentrus that was first collected during a Conservation International (CI) marine biological survey of the southern portion of the Bird's Head Peninsula of western New Guinea (Figure 1) in April 2006. Three specimens were collected at Pulau Karawatu, a tiny islet of less than $1 \mathrm{~km}^{2}$ situated about $13 \mathrm{~km}$ from the New Guinea mainland. A return visit to this location in January 2008 yielded eight additional specimens. Two specimens were also obtained from reefs of the northern Fakfak Peninsula on the same expedition. The fauna of western New Guinea (Papua Barat Province, Indonesia) is poorly documented, but recent investigations by $\mathrm{CI}$ indicate a rich diversity of coral reef fishes including at least 1,407 species (unpublished data).

\section{MATERIALS AND METHODS}

Lengths of specimens are given as standard length (SL) measured from the anterior end of the upper lip to the base of the caudal fin (posterior edge of the hypural plate); head length (HL) is measured from the same anterior point to the posterior edge of the opercle flap; body depth is the maximum depth taken vertically between the belly and base of the dorsal spines; body width is the maximum width just posterior to the gill opening; snout length is measured from the anterior end of the upper lip to the anterior edge of the eye; orbit diameter is the horizontal fleshy diameter, and interorbital width the least fleshy width; upper jaw length is taken from the front of the upper lip to the posterior end of the maxilla; caudal peduncle depth is the least depth, and caudal peduncle length is the horizontal distance between verticals at the rear base of the anal fin and the caudal fin base; lengths of fin spine and rays are measured to their extreme bases (i.e., not from the point where the ray or spine emerges from the basal scaly sheath); caudal fin length is the horizontal length from the posterior edge of the hypural plate to a vertical at the tip of the longest ray; caudal concavity is the horizontal distance between verticals at the tips of the shortest and longest rays; pectoral fin length is the length of the longest ray; pelvic fin length is measured from 


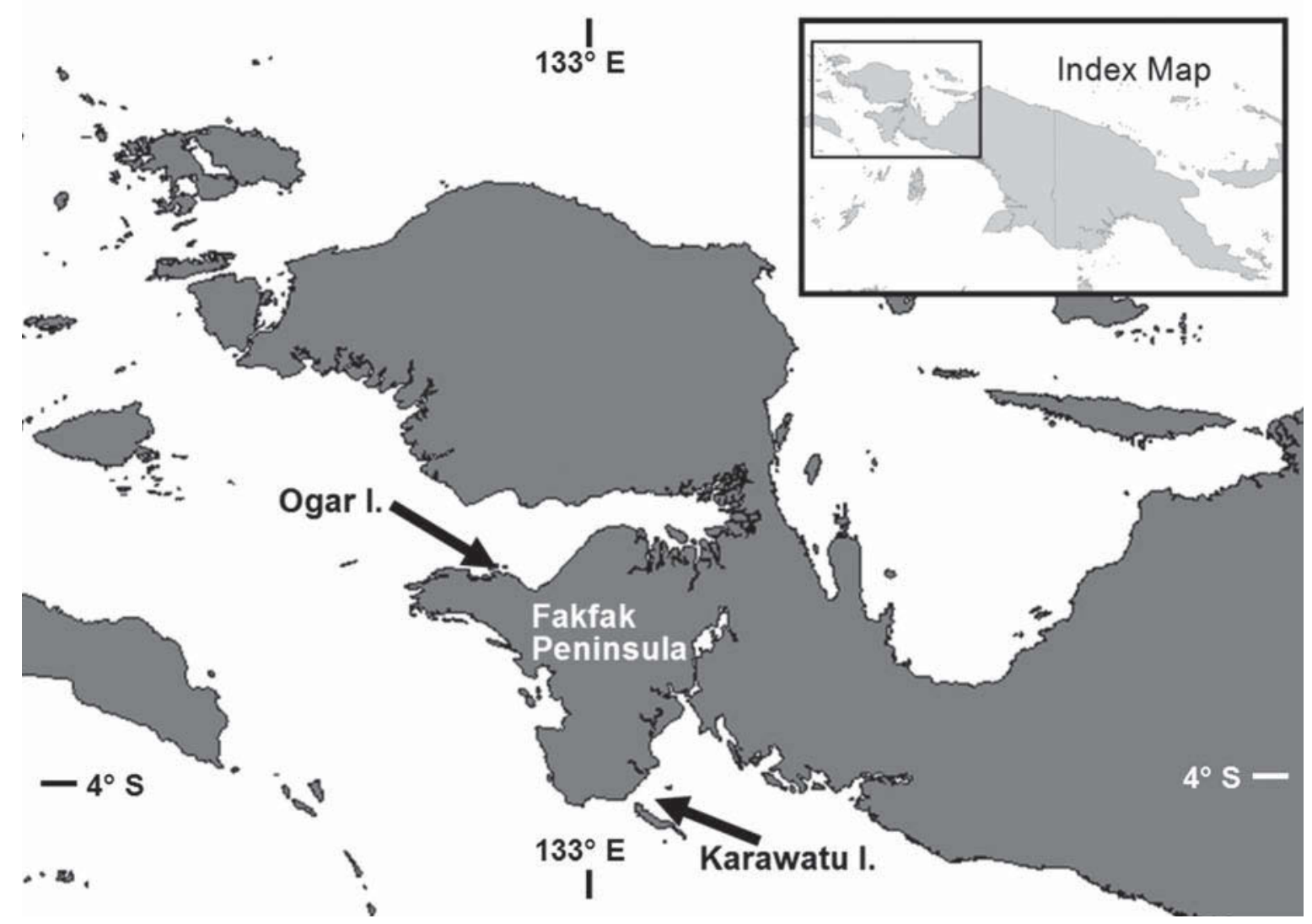

Figure 1. Map of western New Guinea showing approximate collection localities for Pomacentrus fakfakensis. The type locality at Karawatu Island (at arrow tip) and the only other known location for this species at Ogar Island are indicated by the respective lower and upper arrows.

the base of the pelvic spine to the filamentous tip of the longest soft ray; pectoral ray counts include the small splint-like uppermost rudimentary ray; only the tube-bearing anterior lateral-line scales are counted; a separate count is given for the deeply pitted scales occurring in a continuous series midlaterally on the caudal peduncle; the decimal figure " 5 " appearing in the scale row count above and below the lateral line refers to a small truncated scale at the respective bases of the dorsal and anal fins; gill raker counts include all rudiments and are presented as separate counts for the upper and lower limbs as well as a combined count; the last fin ray element of the dorsal and anal fins is usually branched near the base and is counted as a single ray.

Counts and proportions appearing in parentheses apply to the range for the paratypes if different from the holotype. Proportional measurements are expressed as percentage of the standard length and counts for soft dorsal rays, soft anal rays, pectoral rays, total gill rakers on the first arch, and tubed lateral-line scales are presented in Tables 1 and 2. Type specimens are deposited at the National Museum of Natural History, Washington, D.C. (USNM), Pusat Penelitian dan Pengembangan
Oseanologi, Jakarta, Indonesia (NCIP), and Western Australian Museum, Perth (WAM).

\section{SYSTEMATICS}

\section{Family Pomacentridae}

\section{Genus Pomacentrus Lacepède, 1802}

Pomacentrus Lacepède, 1802: 505.

\section{Type species}

Chaetodon pavo Bloch by subsequent designation.

\section{Diagnosis}

Margin of suborbital usually serrate, rarely smooth; margin or preopercle usually with distinct serrations (although weak in several species); notch usually present between preorbital and suborbital; preorbital scaleless except scaled posteriorly in a few species; teeth biserial, at least at front of jaws; dorsal rays XIII or XIV, 12-16; anal rays II, 12-16; pectoral rays 16-19; tubed lateral-line scales 13-19; total gill rakers 17-30; maximum body depth 1.8-2.5 in SL; live colouration variable, usually consisting of shades of brown, grey, yellow, and blue; juvenile 
Table 1 Proportional measurements of selected type specimens of Pomacentrus fakfakensis sp. nov. as percentage of the standard length.

\begin{tabular}{|c|c|c|c|c|c|c|c|c|}
\hline & $\begin{array}{c}\text { Holotype } \\
\text { NCIP } \\
6329\end{array}$ & $\begin{array}{c}\text { Paratype } \\
\text { NCIP } \\
6336\end{array}$ & $\begin{array}{c}\text { Paratype } \\
\text { USNM } \\
391618\end{array}$ & $\begin{array}{c}\text { Paratype } \\
\text { NCIP } \\
6336\end{array}$ & $\begin{array}{c}\text { Paratype } \\
\text { USNM } \\
391618\end{array}$ & $\begin{array}{c}\text { Paratype } \\
\text { WAM } \\
\text { P.32755 }\end{array}$ & $\begin{array}{c}\text { Paratype } \\
\text { USNM } \\
391618\end{array}$ & $\begin{array}{c}\text { Paratype } \\
\text { WAM } \\
\text { P.32755 }\end{array}$ \\
\hline Standard length (mm) & 52.2 & 57.0 & 56.4 & 54.1 & 51.7 & 49.4 & 43.6 & 42.4 \\
\hline Body depth & 47.1 & 49.1 & 50.5 & 48.4 & 48.0 & 50.6 & 49.1 & 47.6 \\
\hline Body width & 17.4 & 21.6 & 21.5 & 20.7 & 19.0 & 19.6 & 19.5 & 17.2 \\
\hline Head length & 31.0 & 33.0 & 33.0 & 32.3 & 32.1 & 32.6 & 32.6 & 33.0 \\
\hline Snout length & 9.4 & 9.8 & 9.8 & 9.8 & 9.3 & 9.1 & 9.2 & 9.0 \\
\hline Orbit diameter & 11.1 & 10.9 & 10.5 & 10.2 & 10.4 & 11.3 & 10.3 & 10.8 \\
\hline Interorbital width & 10.0 & 9.5 & 9.8 & 9.6 & 10.4 & 10.1 & 9.6 & 9.0 \\
\hline Depth of caudal peduncle & 14.6 & 14.9 & 15.8 & 14.2 & 14.5 & 14.6 & 15.4 & 14.6 \\
\hline Length of caudal peduncle & 9.4 & 11.1 & 12.4 & 10.9 & 9.7 & 10.7 & 11.5 & 9.4 \\
\hline Upper jaw length & 9.4 & 9.8 & 9.8 & 10.0 & 9.5 & 9.7 & 9.4 & 9.4 \\
\hline Predorsal distance & 38.1 & 39.6 & 39.5 & 40.3 & 38.1 & 39.7 & 39.7 & 40.1 \\
\hline Preanal distance & 71.1 & 68.2 & 71.3 & 68.8 & 67.3 & 66.0 & 65.8 & 65.3 \\
\hline Prepelvic distance & 41.6 & 40.7 & 41.7 & 39.9 & 39.8 & 39.3 & 40.8 & 39.9 \\
\hline Length of dorsal fin base & 62.5 & 64.2 & 64.9 & 64.3 & 64.8 & 65.0 & 65.6 & 66.0 \\
\hline Length of anal fin base & 27.6 & 28.8 & 28.2 & 27.0 & 28.2 & 29.1 & 28.0 & 30.0 \\
\hline Pectoral fin length & 29.7 & 31.4 & 31.9 & 32.9 & 30.9 & 30.6 & 33.7 & 32.5 \\
\hline Pelvic fin length & 30.7 & 32.6 & 33.7 & 27.9 & 30.0 & 34.4 & 36.7 & 38.2 \\
\hline Pelvic fin spine length & 16.7 & 16.1 & 15.8 & 16.5 & 15.5 & 17.4 & 16.1 & 17.5 \\
\hline 1st dorsal spine & 6.5 & 6.5 & 7.1 & 7.0 & 7.2 & 7.5 & 7.6 & 10.4 \\
\hline 7th dorsal spine & 14.4 & 13.9 & 15.8 & 15.0 & 15.3 & 15.8 & 16.3 & 17.7 \\
\hline Last dorsal spine & 17.2 & 16.7 & 19.1 & 17.6 & 18.0 & 17.4 & 17.9 & 20.3 \\
\hline Longest soft dorsal ray & 22.8 & 22.8 & 23.0 & 23.7 & 26.1 & 24.5 & 24.5 & 27.1 \\
\hline 1st anal spine & 6.7 & 7.4 & 8.7 & 7.2 & 6.6 & 7.1 & 7.8 & 9.0 \\
\hline 2nd anal spine & 17.2 & 18.1 & 18.1 & 17.2 & 16.1 & 18.8 & 19.7 & 20.3 \\
\hline Longest soft anal ray & 21.8 & 21.4 & 21.5 & 21.8 & 22.6 & 23.1 & 22.2 & 23.6 \\
\hline Caudal fin length & 32.8 & 30.2 & 31.2 & 32.3 & 25.3 & 33.2 & 33.3 & 35.8 \\
\hline Caudal concavity & 10.2 & 6.5 & 8.9 & 12.0 & 4.4 & 8.7 & 8.7 & 12.3 \\
\hline
\end{tabular}

stages (under about 30-40 mm SL) frequently with ocellus on soft dorsal fin; maximum size to about 80-90 mm SL.

\section{Pomacentrus fakfakensis sp. nov.} (Figures 2,3 Tables 1,2)

\section{Material examined}

\section{Holotype}

NCIP 6329, 52.2 mm SL, Karawatu Island, 04 $01.803^{\prime} \mathrm{S}, 133^{\circ} 27.711^{\prime} \mathrm{E}$, Papua Barat Province, Indonesia, 4-5 m, spear, G. Allen and M. Erdman, 20 April 2006.

\section{Paratypes}

NCIP 6336, 2 specimens, 54.1-57.0 $\mathrm{mm}$ SL, rocky islets off north-western corner of Ogar Island, $02^{\circ} 371.332^{\prime} \mathrm{S}, 132^{\circ} 24.775^{\prime} \mathrm{E}$, northern Fakfak Peninsula, Papua Barat Province, Indonesia, $3 \mathrm{~m}$, spear, G. Allen, 16 January 2008; USNM 391618, 3 specimens, $43.6-56.4 \mathrm{~mm} \mathrm{SL}$, same location as holotype, 4-6 m, spear and clove oil, G. Allen and
M. Ammer, 13 January 2008; WAM P.32791-005, 2 specimens, 42.4-49.4 $\mathrm{mm}$ SL, collected with holotype; WAM P. 32954-001, 5 specimens, 17.7-50.0 $\mathrm{mm}$ SL, same data as USNM paratypes.

Table 2 Summary of soft dorsal rays, soft anal rays, pectoral rays, gill rakers (GR) on first arch, and tubed lateral-line scales of Pomacentrus fakfakensis sp. nov. Counts for pectoral rays and lateral-line (LL) scales were recorded for both sides of each individual.

\begin{tabular}{|c|c|c|c|c|c|c|}
\hline \multicolumn{2}{|c|}{ Dorsal rays } & \multicolumn{3}{|c|}{ Anal rays } & \multicolumn{2}{|c|}{ Pectoral rays } \\
\hline $13 \quad 14$ & 15 & 13 & 14 & & 17 & 18 \\
\hline 3 & 1 & 3 & 9 & & 5 & 19 \\
\hline \multicolumn{2}{|c|}{ LL scales } & \multicolumn{3}{|c|}{ Upper limb GR } & & \\
\hline 18 & 19 & 56 & 7 & 8 & & \\
\hline 4 & 20 & 5 & 2 & 1 & & \\
\hline \multicolumn{2}{|c|}{ Lower limb GR } & \multicolumn{3}{|c|}{ Total gill rakers } & & \\
\hline 13 & 14 & 19 & 20 & & & \\
\hline 6 & 3 & 5 & 2 & & & \\
\hline
\end{tabular}




\section{Diagnosis}

Dorsal rays XIV,13-15; anal rays II,13-14; pectoral rays usually 18 (occasionally 17); tubed lateral-line scales usually 19 (occasionally 18); gill rakers $5-8+$ 13-14 (total 19-21); body depth 2.0-2.1 in SL; colour in life generally dark brown, including median fins, with small black spot at upper edge of opercle margin; juveniles with ocellus on middle of soft dorsal fin between seventh and eighth soft rays.

\section{Description}

Dorsal rays XIV,14 (XIV,13-15); anal rays II,14 (II, 13 or 14); all dorsal and anal soft rays branched, the last to base; pectoral rays 17-18, lower ray and uppermost pair unbranched; pelvic rays I,5; principal caudal rays 15, median 13 branched; upper and lower procurrent caudal rays 5, posterior pair segmented; scales in longitudinal series 28; tubed lateral-line scales 19 (18 or 19); posterior midlateral scales with a pore or deep pit (in continuous series) 7; scales above lateral line to origin of dorsal fin 3; scales above lateral line to base of middle dorsal spine 1.5; scales below lateral line to origin of anal fin 9; gill rakers $6+13(5-8+13-14)$, total rakers 19 (19-21); pseudobranch filaments 12 (12 or 13).

Body ovate, depth 2.1 (2.0-2.1) in SL, and compressed, width 2.7 (2.3-2.8) in body depth; HL 3.2 (3.0-3.1) in SL; dorsal profile of head evenly rounded from dorsal-fin origin to snout; snout shorter than orbit, its length 3.3 (3.3-3.7) in HL; orbit diameter 2.8 (2.9-3.2) in HL; interorbital space convex, its width 3.1 (3.1-3.7) in HL; caudalpeduncle depth 2.1 (2.1-2.3) in HL; caudal-peduncle length 3.3 (2.7-3.5) in HL.

Mouth terminal, small, and oblique, forming an angle of about $35^{\circ}$ to horizontal axis of head and body; maxilla reaching a vertical about even with anterior edge of pupil, upper-jaw length 3.3 (3.2-3.5) in HL; teeth of jaws uniserial posteriorly, becoming biserial at front of jaws with addition of slender buttress teeth in spaces between main row of larger teeth; teeth incisiform to conical in shape, about 38-42 in each jaw of holotype (excluding buttress teeth). Tongue triangular with rounded tip, set far back in mouth. Gill rakers long and slender, longest on lower limb near angle, about two-thirds length of longest gill filaments. Nostril round with slightly raised rim, level with lower edge of pupil and about midway between anterior edge of eye and upper lip.

Opercle ending posteriorly in flat spine, tip obtuse, barely projecting from beneath a large scale; rear margin of preopercle with 17 serrae on left side of holotype (18-23); preorbital with single serra separated by notch from suborbital series; lower edge of suborbital with 6 serrae; rear edge of posterior circumorbitals without serrae, but may be weakly crenulate.
Scales finely ctenoid; head scaled except lips, tip of snout, preorbital, and suborbital; scaly sheath at base of dorsal and anal fins, averaging about twothirds pupil width at base of dorsal fin and about the same width at base of anterior part of anal fin, gradually tapering in width posteriorly; column of scales on each membrane of dorsal and anal fins, narrowing distally, those on spinous portion of dorsal fin progressively longer, reaching at least two-thirds distance to spine tips on posterior membranes, slightly farther on anterior soft rays, then gradually shorter on posterior part of fin; small scales on caudal fin extending about three-fourths distance to posterior margin; small scales on basal one-fifth of pectoral fins; a cluster of several scales forming median process, extending posteriorly from between base of pelvic fins, its length slightly greater than half that of pelvic spine; axillary scale above base of pelvic spine, its length about twothirds length of pelvic spine.

Origin of dorsal fin over second or third tubed lateral-line scale, predorsal distance 2.6 (2.5-2.6) in SL; base of soft portion of dorsal fin contained about 1.8 times in base of spinous portion; dorsalfin spines gradually increasing in length to last spine; first dorsal spine 4.8 (3.2-5.1) in HL; seventh dorsal spine 2.2 (1.9-2.4) in HL; last dorsal spine 1.8 (1.6-2.0) in HL; membranes of spinous portion of dorsal fin incised near spine tips; seventh dorsal soft ray longest, 1.4 (1.2-1.4) in HL; first anal spine 4.6 (3.7-4.9) in HL; second anal spine 1.8 (1.6-2.0) in HL; longest (ninth) anal soft ray 1.4 (1.4-1.5) in HL; caudal fin moderately forked with angular lobes, its length 3.1 (2.8-3.9) in SL; fourth pectoral ray longest, 3.4 (3.0-3.3) in HL; pelvic spine 1.9 (1.9-2.1) in HL; first soft ray of pelvic fin forming filamentous tip, $3.3(2.6-3.6)$ in SL.

Colour when alive/freshly collected: adult (Figures 2-3) overall dark brown, including median fins, slightly lighter on breast and belly; pectoral and pelvic fins translucent with faintly dusky brown rays, anterior edge of pelvic fin dark brown.

Colour in alcohol: generally dark brown including median fins; small blackish spot occupying most of small scale at upper rear margin of operculum; pelvic and pectoral fins tan. Smallest paratype (42.4 mm SL) with faint dark spot, a remnant of juvenile ocellus, in middle of posterior dorsal fin between seventh and eighth soft rays.

\section{Remarks}

The new species generally resembles several other nondescript, mainly dark brown Pomacentrus from the western Pacific including $P$. armillatus Allen (Borneo and Philippines), P. bintanensis Allen (Bintan Island, Indonesia), P. burroughi Fowler (widespread Indo-Malayan region), P. cuneatus Allen (widespread Indo-Malayan region), P. komodensis 


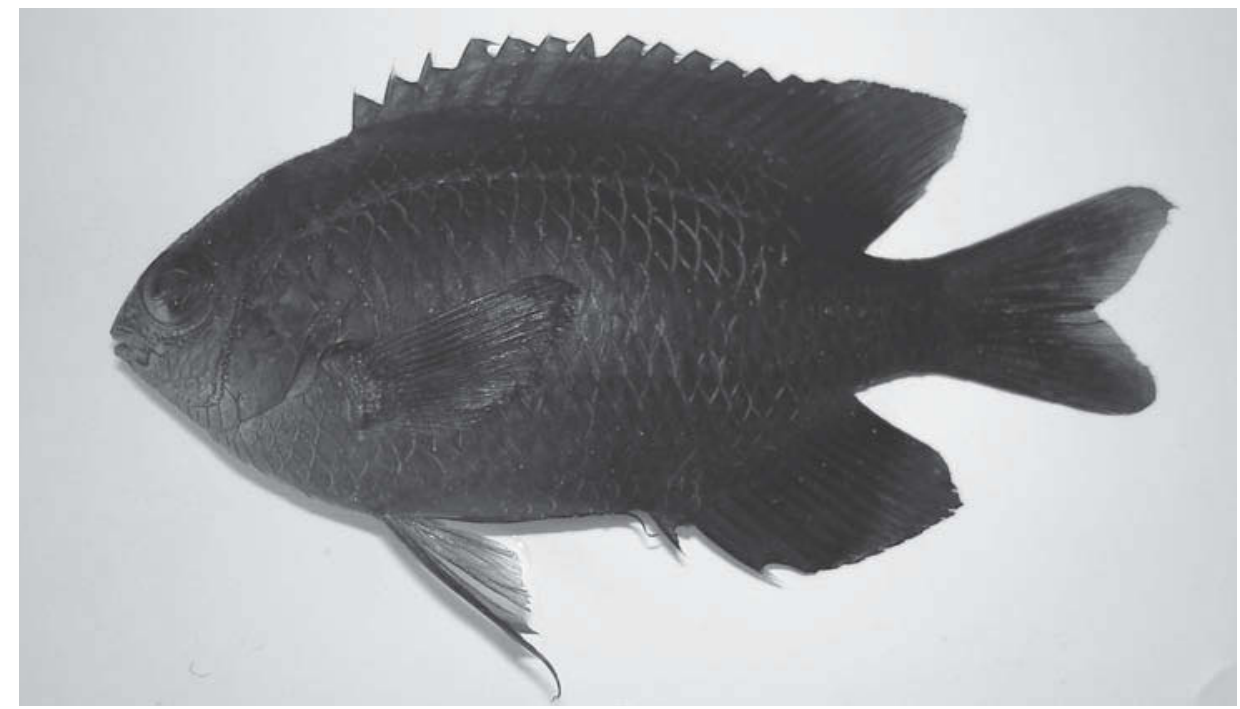

Figure 2 Pomacentrus fakfakensis sp. nov., holotype, $52.2 \mathrm{~mm} \mathrm{SL}$, Karawatu Island, Papua Barat Province, Indonesia.

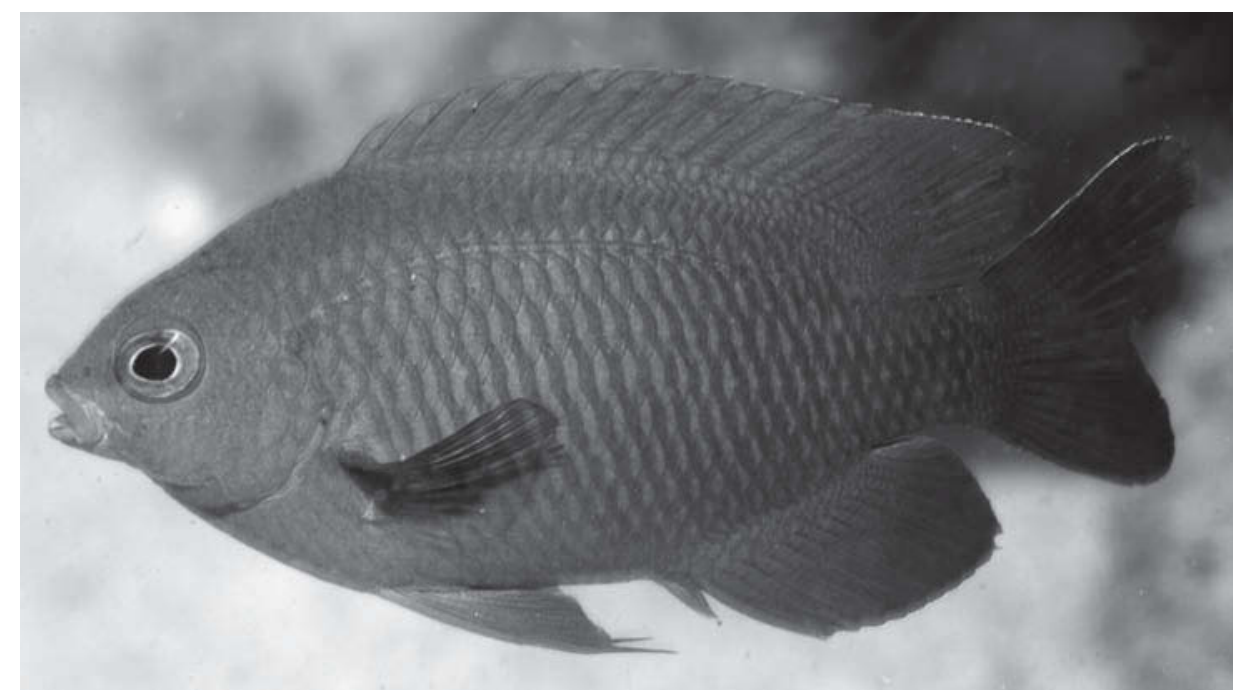

Figure 3 Underwater photograph of Pomacentrus fakfakensis sp. nov., approximately $50.0 \mathrm{~mm}$ SL, Ogar Island, Papua Barat Province, Indonesia.

Allen (Komodo Island, Indonesia), P. littoralis Cuvier (widespread western Pacific), P. melanochir Bleeker (eastern Indonesia), P. opisthostigma Fowler (widespread Indo-Malayan region), P. tripunctatus Cuvier (widespread western Pacific and eastern Indian Ocean), and P. wardi Whitley (eastern Australia). It differs from all these species except $P$. armillatus and P. opisthotostigma in having 14 instead of 13 dorsal spines (see Allen 1991 for diagnoses of these and other Pomacentrus). Both of these species are readily distinguished from $P$. fakfakensis in having distinctive dark markings on the pectoralfin base; that of $P$. armillatus forms a bar across the entire fin base, while that of $P$. opisthostigma forms a wedge-shaped mark restricted to the upper fin base. These two species also differ in having fewer lateral-line scales (usually 15-17 versus 18-19), fewer pectoral rays (17 versus mainly 18) and more gill rakers on the first arch (26-29 versus 19-21).

The new species is currently known only from south-western New Guinea (Papua Barat Province, Indonesia) at Karawatu Island and the northern coast of the Fakfak Peninsula in the vicinity of Kokas Village. It was relatively common at both locations on silt-affected reef flats around coral and rock outcrops at depths of 2-8 m.

\section{Etymology}

The new species is named fakfakensis with reference to the Fakfak Peninsula of western New Guinea, the only known location for this species.

\section{ACKNOWLEDGEMENTS}

We are especially grateful to Conservation International and the Indonesian Department of 
Nature Conservation (PHKA) for sponsoring the 2006 expedition to Triton Bay and especially to the Walton Family Foundation for their interest and generous support of CI's Bird's Head Seascape marine conservation initiative. We also thank the crew of the live-aboard dive boat Citra Pelangi for their excellent logistic support during the 2006 visit to Triton Bay. Graham Abbot served as Cruise Director and greatly assisted with logistics. Special thanks are also due Max Ammer, who chartered the vessel Helena for the return visit in 2008 and assisted with collections.

\section{REFERENCES}

Allen G.R. (1991). Damselfishes of the World. Mergus: Melle, Germany.

Allen, G.R. (1992). A new species of damselfish (genus Pomacentrus) from north-western Australia. Records of the Western Australian Museum 15: 697-701.

Allen, G.R. (1993). Two new species of damselfishes (Pomacentrus), with comments on the validity of two additional pomacentrid fishes. Revue Française Aquariologie Herpetologie 20: 21-26.

Allen, G.R. (1995). Two new species of damselfishes (Pomacentridae) from Indonesian seas. Revue Française Aquariologie Herpetologie 21: 86-90.

Allen, G.R. (1999). Three new species of damselfishes
(Pomacentridae) from Indonesia and eastern Papua New Guinea. Revue Française Aquariologie Herpetologie 25: 99-106.

Allen, G.R. (2002). Descriptions of two new species of damselfishes (Pomacentridae: Pomacentrus) from Madagascar. Aqua, Journal of Ichthyology and Aquatic Biology 6: 45-52.

Allen, G.R. (2004). Pomacentrus aurifrons, a new species of damselfish Pomacentridae) from Melanesia. Zootaxa 399: 1-7.

Allen, G.R., and Erdmann, M.V. (2005). Chromis xouthos, a new species of damselfish (Pomacentridae) from the east Andaman Sea and central Indian Ocean. Aqua, Journal of Ichthyology and Aquatic Biology 10: 89-94.

Allen, G.R. and Randall, J.E. (2004). Two new species of damselfishes (Pomacentridae) from Micronesia. Aqua, Journal of Ichthyology and Aquatic Biology 9: 75-87.

Allen, G.R., and Randall, J.E. (2005). A new species of damselfish (Pomacentrus: Pomacentridae) from Fiji. Aqua, Journal of Ichthyology and Aquatic Biology 10: 95-102.

Allen, G.R. and Wright, J.E. (2003). Description of a new species of damselfish (Pomacentridae: Pomacentrus) from Rodrigues Island, Indian Ocean. Aqua, Journal of Ichthyology and Aquatic Biology 7: 133-138.

Randall, J.E. (2002). Two new damselfishes of the genus Pomacentrus from the south-west Pacific. Aqua, Journal of Ichthyology and Aquatic Biology 5: 167-176.

Manuscript received 19 March 2008; accepted 7 July 2008. 